\title{
Twenty-year Experience with Genitourinary Lymphoma at a Community Hospital
}

\author{
Yazhini Vallatharasu, MD; Adithya Chennamadhavuni, MD; and Marvin J. Van Every, MD
}

Introduction: Non-Hodgkin lymphoma is the seventh most common cancer in the United States. It may involve any extranodal organ, although involvement of the genitourinary (GU) tract accounts for $<5 \%$ of all primary extranodal lymphomas. Published GU lymphoma literature is currently limited to small case series and case reports. The last substantial American series was published in 2009. Our objective was to characterize cases of GU lymphoma from our institution based on organ involved and to review relevant literature.

Patients and Methods: After institutional review board approval, we retrospectively reviewed medical records of patients diagnosed with lymphoma involving the GU organs from 1995 through 2015. Patients with obstructive uropathy from retroperitoneal adenopathy without parenchymal involvement of a GU organ were excluded. We classified extranodal GU lymphomas as primary or secondary, based on involvement of other organs and distant lymphadenopathy.

Results: Thirty-six patients had lymphoid neoplasms involving the kidney, ureters, bladder, testis, penile skin, or prostate in our health system during the study period. Of these, $15(41.6 \%)$ were primary. Most patients initially sought consultation for GU-related symptoms, such as bladder obstruction, hematuria, testicular mass, or abdominal pain. Histological subtypes and flow cytometry findings varied broadly.

Conclusion: Our series reports site-specific outcomes data and adds detail to findings from other published series. Although GU lymphomas are rare, our series confirms prior studies demonstrating presentation in urologic organs. They should be considered in the differential diagnosis in all patients, especially those with unusual findings on examination, cystoscopy, or computed tomography scan.

Keywords: Genitourinary neoplasms; Non-Hodgkin; Community health centers;

Disease-free survival; Incidence

$\mathrm{N}$ on-Hodgkin lymphomas (NHLs) are malignant lymphoid neoplasms derived from B-cell or T-cell progenitors, mature $\mathrm{B}$ or $\mathrm{T}$ cells, and, rarely, natural killer cells. NHL is the seventh most common cancer in the United States. ${ }^{1}$ It appears predominantly as adenopathy, although it can present with extranodal involvement without adenopathy. NHL may involve any extranodal organ, although solitary involvement of the genitourinary (GU) tract is relatively rare and accounts for less than $5 \%$ of all primary extranodal lymphomas. ${ }^{2}$ The GU lymphoma literature is currently limited to small case series and case reports, with the last substantial American series having been published in $2009 .{ }^{2}$ The objective of our study was to clinically characterize the cases of GU lymphoma from our institution based on the
Corresponding Author: Marvin J. Van Every, MD, Mail Stop C03-006B Gundersen Health System, 1900 South Avenue, La Crosse, WI 5460I, Telephone: (608) 775-6648, Facsimile: (608) 775-I565, Email: marvvanevery@icloud.com

Disclosures: This project received no financial support from funding agencies in the public, commercial, or not-for-profit sectors. The authors have no conflicts of interest to disclose.
Received: October 30, 2019

Ist Revision: September 22, 2020

2nd Revision: December 8, 2020

Accepted: January 8, 2021

doi: $|0.3| 2|/ \mathrm{cmr} .202| .|53|$ 
organ involved. We hypothesized this series may provide useful information for practicing urologists and hematologists when evaluating and treating these rare cases.

\section{Methods}

Following approval by the Gundersen Clinic, Ltd. Human Subjects Committee/Institutional Review Board, we requested from our cancer registry a list of patients who were diagnosed with lymphoma involving any GU organ in our health system during the years 1995 through 2014. Lymphoproliferative malignancies forming tumor masses in the GU tract, such as lymphoblastic lymphoma/leukemia (myeloid sarcomas) and plasmacytoma, were not included in the study. Patients with obstructive uropathy from retroperitoneal adenopathy without parenchymal involvement of a GU organ were also excluded. We then retrospectively reviewed the medical records of these patients. From the medical records, we captured demographic, clinical, and laboratory data. Individual treatments were not collected. We used the criteria proposed by Dawson $^{3}$ in 1961 to classify extranodal lymphomas as primary or secondary. Dawson defined primary extranodal lymphoma as presentation with main disease manifestation in the extranodal site, with or without involvement of regional lymph nodes. Including stage III and IV disease as primary extranodal lymphoma is controversial. The general consensus among authors is to include only stage I and II as primary extranodal lymphoma. ${ }^{4,5}$ Therefore, we classified only patients with GU lymphoma with or without a regional lymph node as primary and the rest as secondary.

\section{Results}

Thirty-six patients were diagnosed with lymphoid neoplasms involving the prostate, kidney, bladder, testis, or penis in our health system during the study period. Of these, $15(41.6 \%)$ had primary GU lymphomas, and the other 21 (58.4\%) had secondary GU lymphomas. Most patients were prompted to seek care for GU-related symptoms, such as bladder obstruction, hematuria, testicular mass, or abdominal pain.

\section{Prostate}

Six patients had prostatic involvement (Table 1). Patients had a mean age of 61 years (range, 54-80 years). The most common presentation was an enlarged prostate causing prostatism. Of the six patients, four had primary prostate lymphoma. Three patients had chronic lymphocytic leukemia (CLL) and survived an average of 10 years with no evidence of disease.

\section{Kidney}

Seven patients had renal involvement (Table 2). One of the seven patients had primary renal lymphoma with diffuse large B-cell lymphoma (DLBCL) histology. Patients had a mean age of 67 years (range, 37-86 years). Five of the seven patients were women. The most common presentations were

Table 1. Demographic, Clinical, and Outcome Data of 6 Patients with Lymphoma of the Prostate Gland

\begin{tabular}{|c|c|c|c|c|c|c|c|}
\hline $\begin{array}{l}\text { Age at } \\
\text { Diagnosis } \\
\text { (y) }\end{array}$ & Other Site & $\mathbf{P}$ or $\mathrm{S}^{*}$ & $\begin{array}{c}\text { Signs \& } \\
\text { Symptoms }\end{array}$ & Type & $\begin{array}{l}\text { Specimen } \\
\text { Obtained }\end{array}$ & $\begin{array}{l}\text { Associated } \\
\text { Disease }\end{array}$ & Outcome \\
\hline 56 & none & $P$ & enlarged prostate & CLL & prostate & none & $\begin{array}{l}\text { NED, } \\
10 y\end{array}$ \\
\hline 56 & $\begin{array}{l}\text { right cervical, right } \\
\text { external iliac nodes }\end{array}$ & $\mathrm{S}$ & hematuria & DLBCL & prostate & none & $\begin{array}{l}\text { DWD, } \\
21 \mathrm{mo}\end{array}$ \\
\hline 65 & $\begin{array}{c}\text { peripheral } \\
\text { lymphocytosis }\end{array}$ & $P$ & enlarged prostate & CLL & prostate & $\begin{array}{l}\text { left renal } \\
\text { carcinoma }\end{array}$ & $\begin{array}{l}\text { NED, } \\
10 y\end{array}$ \\
\hline 54 & none & $\mathrm{P}$ & $\begin{array}{c}\text { elevated PSA; } \\
\text { prostate biopsy } \\
\text { showed } \\
\text { adenocarcinoma and } \\
\text { B-cell CLL }\end{array}$ & CLL & prostate & $\begin{array}{c}\text { prostate } \\
\text { adeno- } \\
\text { carcinoma }\end{array}$ & $\begin{array}{l}\text { NED, } \\
10 y\end{array}$ \\
\hline 57 & scalp, adrenal, urethra & $\mathrm{S}$ & $\begin{array}{l}\text { lower urinary tract } \\
\text { symptom }\end{array}$ & $\begin{array}{l}\text { DLBCL } \\
\text { recurrence }\end{array}$ & prostate & none & $\begin{array}{l}\text { DWD, } \\
12 \mathrm{mo}\end{array}$ \\
\hline 80 & none & $\mathbf{P}$ & $\begin{array}{l}\text { hematuria, increased } \\
\text { frequency }\end{array}$ & $\begin{array}{l}\text { low-grade } \\
\text { NHL-NOS }\end{array}$ & prostate & none & DWD \\
\hline
\end{tabular}

Abbreviations: P or S, primary or secondary; PSA, prostate-specific antigen; CLL, chronic lymphocytic leukemia; DLBCL, diffuse large B-cell lymphoma; NHL-NOS, non-Hodgkin lymphoma-not otherwise specified; NED, no evidence of disease; DWD, died with disease *Patients with GU lymphoma with or without a regional lymph node were classified as primary and the rest as secondary. 
Table 2. Demographic, Clinical, and Outcome Data of 7 Patients with Lymphoma of the Kidney

\begin{tabular}{|c|c|c|c|c|c|c|c|c|c|}
\hline $\begin{array}{l}\text { Age at } \\
\text { diagnosis } \\
\text { (y) }\end{array}$ & Sex & Site & Other Site & $\mathbf{P}$ or $\mathbf{S}^{*}$ & $\begin{array}{c}\text { Signs \& } \\
\text { Symptoms }\end{array}$ & Type & $\begin{array}{l}\text { Specimen } \\
\text { Obtained }\end{array}$ & $\begin{array}{l}\text { Associated } \\
\text { Disease }\end{array}$ & Outcome \\
\hline 86 & $M$ & kidney & $\begin{array}{c}\text { bones, } \\
\text { paraspinal, } \\
\text { pleural, lymph } \\
\text { nodes }\end{array}$ & $S$ & $\begin{array}{l}\text { obstructive } \\
\text { uropathy }\end{array}$ & $\begin{array}{c}\text { follicular } \\
\text { low-grade } \\
\text { NHL }\end{array}$ & $\begin{array}{l}\text { perinephric } \\
\text { mass }\end{array}$ & none & $\begin{array}{l}\text { NED, } \\
7 \mathrm{y}\end{array}$ \\
\hline 74 & $F$ & $\begin{array}{c}\text { left } \\
\text { kidney }\end{array}$ & $\begin{array}{l}\text { retroperitoneal } \\
\text { lymph nodes }\end{array}$ & $\mathrm{S}$ & $\begin{array}{l}\text { abdominal } \\
\text { pain }\end{array}$ & DLBCL & $\begin{array}{l}\text { kidney mass, } \\
\text { lymph node } \\
\text { biopsy }\end{array}$ & none & $\begin{array}{c}\text { NED, } \\
3 \mathrm{y} ; \\
\text { however, } \\
\text { alive with } \\
\text { metastatic } \\
\text { colon } \\
\text { cancer }\end{array}$ \\
\hline 69 & $F$ & $\begin{array}{l}\text { right } \\
\text { kidney }\end{array}$ & $\begin{array}{l}\text { mediastinal } \\
\text { lymph nodes, } \\
\text { retroperitoneal } \\
\text { lymph node }\end{array}$ & $\mathrm{S}$ & back pain & DLBCL & right kidney & none & $\begin{array}{l}\text { DWD, } \\
3 \mathrm{mo}\end{array}$ \\
\hline 78 & $F$ & $\begin{array}{c}\text { left } \\
\text { kidney }\end{array}$ & none & $P$ & $\begin{array}{l}\text { abdominal } \\
\text { pain }\end{array}$ & DLBCL & $\begin{array}{l}\text { kidney mass, } \\
\text { lymph node } \\
\text { biopsy }\end{array}$ & none & $\begin{array}{l}\text { DWD, } \\
5 \mathrm{mo}\end{array}$ \\
\hline 58 & $F$ & $\begin{array}{l}\text { right } \\
\text { kidney }\end{array}$ & $\begin{array}{c}\text { cervical lymph } \\
\text { nodes }\end{array}$ & $S$ & $\begin{array}{c}\text { palpable } \\
\text { lymph- } \\
\text { adenopathy }\end{array}$ & DLBCL & $\begin{array}{c}\text { cervical } \\
\text { lymph node }\end{array}$ & none & $\begin{array}{l}\text { DWD, } \\
12 \mathrm{mo}\end{array}$ \\
\hline 37 & $F$ & $\begin{array}{c}\text { left } \\
\text { kidney }\end{array}$ & $\begin{array}{l}\text { lymph nodes, } \\
\text { bone }\end{array}$ & $S$ & $\begin{array}{l}\text { dizzy spells, } \\
\text { weight loss, } \\
\text { night sweats }\end{array}$ & $\begin{array}{c}\text { follicular } \\
\text { high-grade } \\
\text { NHL }\end{array}$ & $\begin{array}{l}\text { right inguinal } \\
\text { lymph node } \\
\text { biopsy }\end{array}$ & none & NED \\
\hline 66 & $M$ & $\begin{array}{c}\text { left } \\
\text { kidney }\end{array}$ & CNS & $S$ & $\begin{array}{l}\text { obstructive } \\
\text { uropathy }\end{array}$ & DLBCL & $\begin{array}{c}\text { biopsy of } \\
\text { kidney mass }\end{array}$ & none & $\begin{array}{l}\text { DWD, } \\
2 \mathrm{y}\end{array}$ \\
\hline
\end{tabular}

Abbreviations: P or S, primary or secondary; CNS, central nervous system; NHL, non-Hodgkin lymphoma; DLBCL, diffuse large B-cell lymphoma; NED, no evidence of disease; DWD, died with disease.

*Patients with GU lymphoma with or without a regional lymph node were classified as primary and the rest as secondary.

abdominal pain and obstructive uropathy causing renal failure. Three of seven died with disease, with an average survival of 11 months (range, 3-24 months). Of our patients with GU involvement, those with renal involvement had the lowest survival.

\section{Bladder}

Vesicular involvement (Table 3) was more common in men than in women $(75 \%$ vs $25 \%$, respectively). Average age at presentation was 76 years (range, $71-85$ years). Our patients' diagnoses were made when the disease was either detected incidentally or when the patient sought care for any of a range of symptoms from obstruction to hematuria. Five of our eight patients had primary bladder lymphoma. Only one patient with vesicular involvement died with disease.

Testis

Of our 36 patients, 14 had testicular lymphomas (Table 4). Mean patient age was 68 years, but age ranged widely (38-80 years). DLBCL was the most common histology. Of the 14 patients, six had primary testicular lymphoma. No patient with testicular lymphoma was noted to have HIV or AIDS. All patients presented with testicular enlargement, and the initial diagnostic specimens were from orchiectomy. Of the 14 cases, 10 had prolonged survival of more than 4 years.

Penis

One patient, aged 65 years, had a penile lesion. The disease extended onto the foreskin. He had a penectomy, and the pathology specimen was found to have small lymphocytic lymphoma (SLL). The patient died with disease 22 months from the date of diagnosis.

\section{Discussion}

Diagnosis of GU lymphoma is usually made with histological examination and flow cytometry as an adjunct when necessary. Immunohistochemistry and fluorescence in situ hybridization (FISH) aid in identifying the cell of origin and the subtype of 
Table 3. Demographic, Clinical, and Outcome Data of 8 Patients with Lymphoma of the Bladder

\begin{tabular}{|c|c|c|c|c|c|c|c|c|c|}
\hline $\begin{array}{l}\text { Age at } \\
\text { Diagnosis } \\
\text { (y) }\end{array}$ & Sex & Site & Other Sites & $\mathbf{P}$ or $\mathbf{S}^{*}$ & $\begin{array}{c}\text { Signs \& } \\
\text { Symptoms }\end{array}$ & Type & $\begin{array}{c}\text { Specimen } \\
\text { Obtained }\end{array}$ & $\begin{array}{l}\text { Associated } \\
\text { Disease }\end{array}$ & Outcome \\
\hline 71 & $M$ & bladder & none & $P$ & $\begin{array}{c}\text { regular } \\
\text { surveillance } \\
\text { cystoscopy }\end{array}$ & $\begin{array}{l}\text { high-grade } \\
\text { follicular } \\
\text { NHL }\end{array}$ & $\begin{array}{c}\text { bladder } \\
\text { cystoscopy, } \\
\text { prostate }\end{array}$ & $\begin{array}{l}\text { transitional } \\
\text { cell } \\
\text { carcinoma }\end{array}$ & NED \\
\hline 72 & $M$ & bladder & $\begin{array}{c}\text { retroperitoneal } \\
\text { lymphadenopathy }\end{array}$ & $\mathrm{S}$ & $\begin{array}{l}\text { fever, weight } \\
\text { loss, cough }\end{array}$ & $\begin{array}{c}\text { Hodgkin } \\
\text { lymphoma }\end{array}$ & TURB-T & none & $\begin{array}{c}\text { NED, } \\
3 \mathrm{y}\end{array}$ \\
\hline 76 & $F$ & bladder & $\begin{array}{c}\text { external iliac } \\
\text { nodes }\end{array}$ & $\mathrm{S}$ & hematuria & DLBCL & $\begin{array}{l}\text { bladder } \\
\text { mass }\end{array}$ & none & NED \\
\hline 78 & $\mathrm{~F}$ & bladder wall & $\begin{array}{l}\text { left external iliac } \\
\text { node }\end{array}$ & $\mathrm{P}$ & hematuria & DLBCL & bladder wall & none & $\begin{array}{l}\text { NED, } \\
8 \mathrm{y}\end{array}$ \\
\hline 71 & $M$ & bladder & right axilla & $S$ & $\begin{array}{l}\text { new lesions } \\
\text { found on } \\
\text { cystoscopy } \\
\text { for follow-up } \\
\text { of bladder } \\
\text { cancer }\end{array}$ & $\begin{array}{c}\text { high-grade } \\
\text { follicular } \\
\text { NHL }\end{array}$ & bladder & $\begin{array}{l}\text { MGUS, } \\
\text { transitional } \\
\text { bladder } \\
\text { cancer }\end{array}$ & $\begin{array}{l}\text { NED, } \\
81 / 2 y\end{array}$ \\
\hline 85 & $M$ & $\begin{array}{l}\text { uretero- } \\
\text { vesicular } \\
\text { junction }\end{array}$ & none & $P$ & $\begin{array}{l}\text { obstructive } \\
\text { uropathy }\end{array}$ & DLBCL & $\begin{array}{c}\text { mass around } \\
\text { distal ureter }\end{array}$ & none & $\begin{array}{l}\text { DWD, } \\
21 / 2 \text { y }\end{array}$ \\
\hline
\end{tabular}

Abbreviations: P or S, primary or secondary; NHL, non-Hodgkin lymphoma; NOS, not otherwise specified; DLBCL, diffuse large B-cell lymphoma; TURB-T, transurethral resection of the bladder tumor; MGUS, monoclonal gammopathy of undetermined significance; NED, no evidence of disease; DWD, died with disease.

*Patients with GU lymphoma with or without a regional lymph node were classified as primary and the rest as secondary.

lymphoma, which has prognostic value. Positive emission tomography and bone marrow examination are essential in ruling out systemic disease. Chemotherapy - whether R-CHOP, DA-R-EPOCH, or R-Hyper-CVAD — with or without radiation, is the most commonly employed management strategy in patients with high-grade lymphoma. Owing to selection bias, prognosis of primary GU lymphomas may be better than that of lymphomas without GU involvement, because patients with primary GU lymphoma, by our definition, have low-volume disease. This may not be true with renal DLBCL though, because we know that renal involvement is a predictor of highrisk disease and central nervous system (CNS) recurrence. Regardless of the organ involved, prognosis is dependent on the grade, stage, bone marrow involvement, International Prognostic Index (IPI) risk score, cell of origin, and, in the case of DLBCL, presence of adverse genetic factors. Our case series provides site-specific outcomes data and underlines the complications observed in GU lymphomas, adding to findings from other published case series.
Prostate

Primary lymphoma of the prostate is extremely rare, representing only $0.2 \%$ to $0.8 \%$ of extranodal lymphoma and $0.1 \%$ of all prostate cancers. ${ }^{6}$ The existence of primary extranodal prostatic lymphoma is debatable because of the deficiency of lymphoid tissue in the prostate, but some researchers believe the presence of rudimentary lymphoid nodules and extramedullary hematopoiesis in the prostate may give rise to primary lymphoma. ${ }^{7,8}$ The most common prostate malignancy is adenocarcinoma, representing more than $95 \%$ of all cases. In a case series by Bostwick et al, ${ }^{9} 22$ patients with a mean age of 66 years had primary lymphoma of the prostate. Nine patients died of lymphoma, with a median survival of 23 months (range, 2-30 months). Seven patients were alive 5 years after diagnosis. In most of the case series, DLBCL was the most common histology. In our series, CLL/SLL was the most common histological subtype. 
Tissue diagnosis can sometimes be challenging, because the sensitivity of needle biopsy is lower (only 22.2\%) due to irregular prostatic infiltration by malignant lymphocytes, which are difficult to distinguish from prostatitis, prostate cyst or abscess, small-cell carcinoma, lymphoepithelioma-like carcinoma, and Hodgkin lymphoma. ${ }^{10}$ Co-existing lymphoma and adenocarcinoma in the same prostate, as found in one of our cases, and prostatic infiltration by lymphoma cells also must be ruled out (Figures $1 \& 2$ ). These patients are usually treated with surgery, radiation, or chemotherapy, depending on the type of lymphoma and symptoms associated with it. High-grade lymphomas usually require chemotherapy, whereas low-grade lymphomas can be treated with radiation or surgery if they are symptomatic. Prognosis might differ based on the type and grade of the lymphoma, as is the case with nodal lymphomas. One might assume that patients with primary prostate lymphoma have a better prognosis because, based on the definition of primary GU lymphoma, these

Table 4. Demographic, Clinical, and Outcome Data of 14 Patients with Testicular Lymphoma

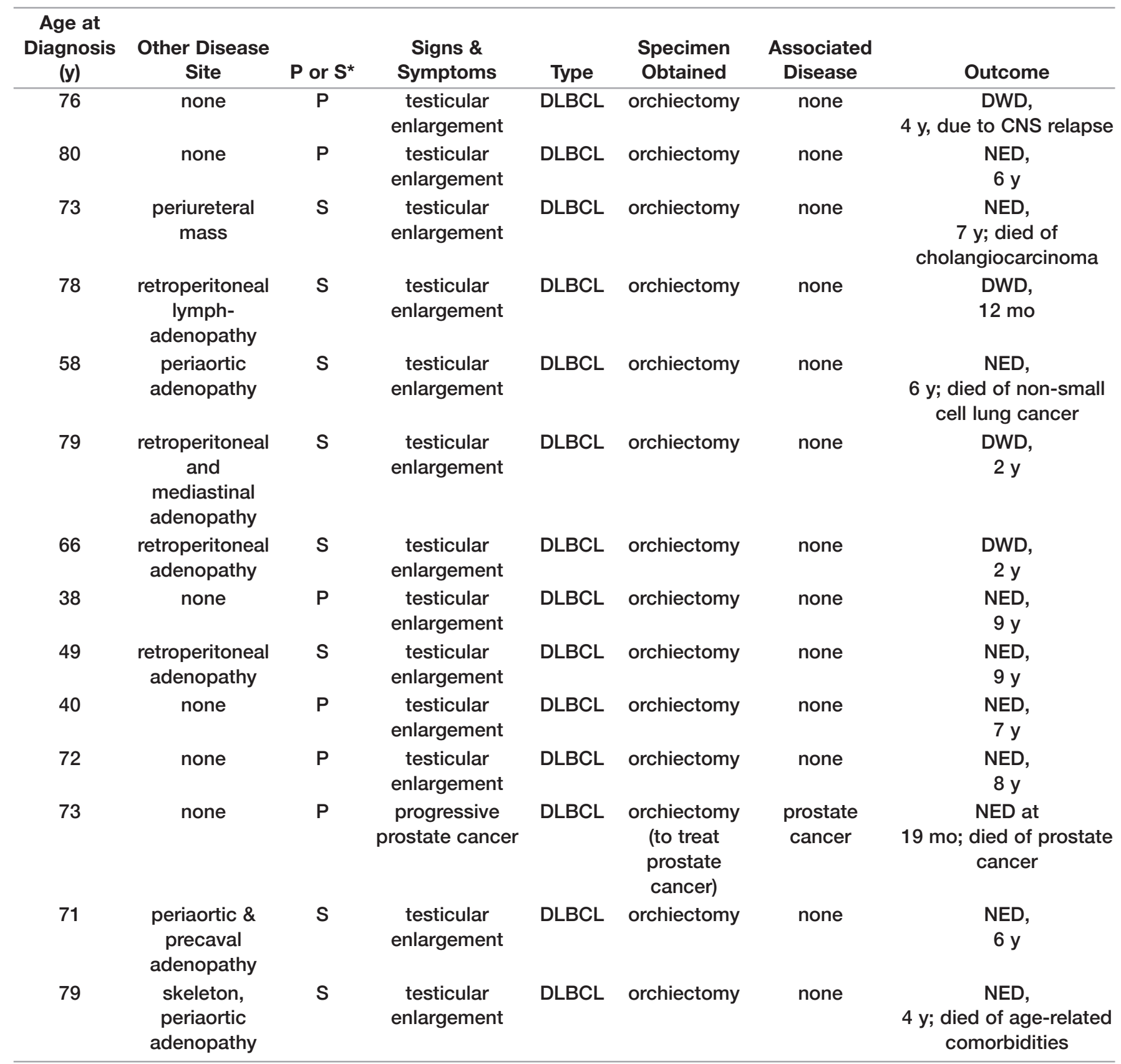

Abbreviations: P or S, primary or secondary; DLBCL, diffuse large B-cell lymphoma; NED, no evidence of disease; CNS, central nervous system; DWD, died with disease.

*Patients with GU lymphoma with or without a regional lymph node were classified as primary and the rest as secondary. 


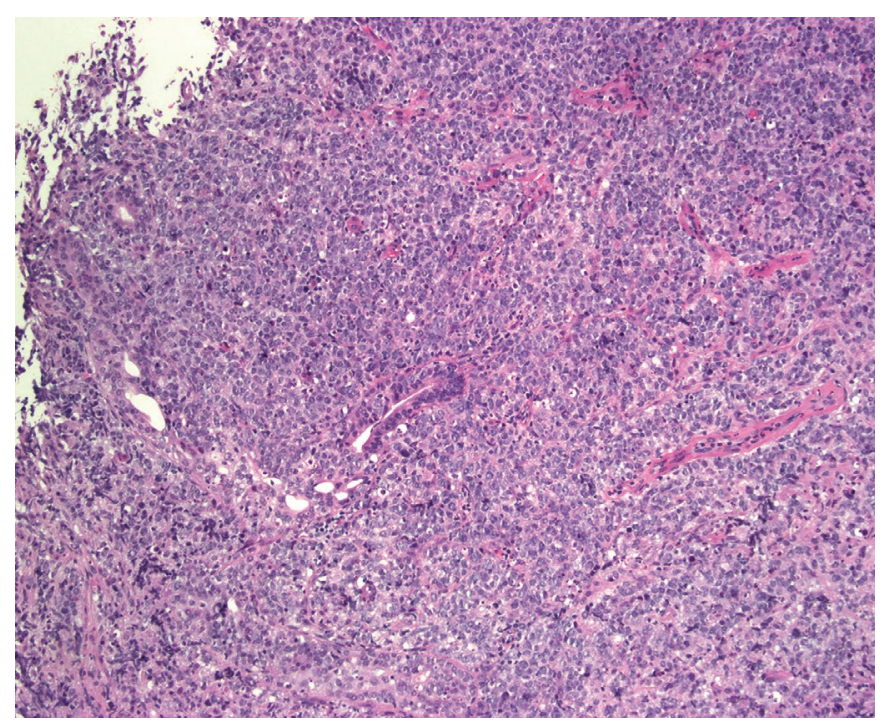

Figure 1. Hematoxylin \& Eosin stain. Large cytologically malignant lymphoid cells with nuclear pleomorphism diffusely infiltrating and replacing prostatic stroma with occasional residual prostatic glands.

patients have local disease only. On rare occasion, in our experience, the diagnosis of lymphoma can be made when enlarged lymph nodes demonstrate lymphoma and not prostate cancer in patients undergoing open or robotic prostatectomy with pelvic lymph node dissection.

\section{Kidney}

Secondary renal involvement in lymphoma is very common. In an autopsy series, incidence was reported to be $47 \%$, but it was clinically recognized in only about $15 \%$ of patients. ${ }^{11}$ In

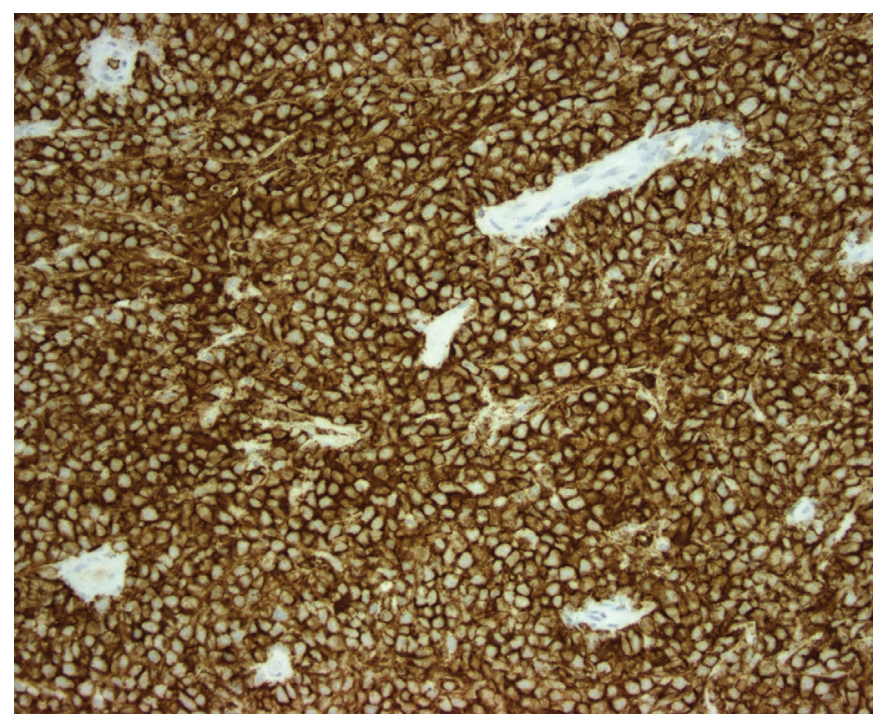

Figure 2. Immunohistochemical stain of prostate tissue demonstrating pan-B-cell marker CD20 (positive immunostaining). contrast, primary renal lymphoma is rare; indeed, its existence has been questioned, because the kidney is not a lymphoid organ. Pathologic mechanisms that have been proposed are origin in the subcapsular lymphatics, seeding via hematogenous route, an extension from retroperitoneal disease, and inflammatory disease with a lymphoplasmacytic infiltrate. ${ }^{12}$

Primary renal lymphoma has been associated with inflammatory and chronic infectious diseases, such as chronic pyelonephritis, Sjögren syndrome, systemic erythematous lupus, or Epstein-Barr virus. ${ }^{13}$ It is more common in middleaged men, although five of seven patients in our study were women. It may manifest as a solitary mass $(10 \%-20 \%)$ or multiple masses $(60 \%)$, and extends by contiguity $(25 \%$ $30 \%$ ), diffuse infiltration $(20 \%)$, or perirenal involvement $(10 \%) .{ }^{14}$ Presenting symptoms are usually similar to those of renal cell carcinoma, such as abdominal pain, hematuria, or urinary obstruction. It can also present with proteinuria or nephrotic syndrome and rapidly progress to renal failure when both kidneys are affected. The most common histology is DLBCL (in our series, it was follicular lymphoma) (Figures 3 \& 4). On imaging, primary renal lymphoma can be indistinguishable from renal cell carcinoma, although on computed tomography (CT) scan there can be clues to guide the diagnosis. Primary renal lymphoma usually appears as a hypervascularized mass with minimal and homogeneous contrast enhancement (Figure 5). Other clues to primary renal lymphoma on CT are sinus or hilum directly infiltrated by a bulky mass or diffuse retroperitoneal infiltration. Despite these differences on imaging, a biopsy is always required to

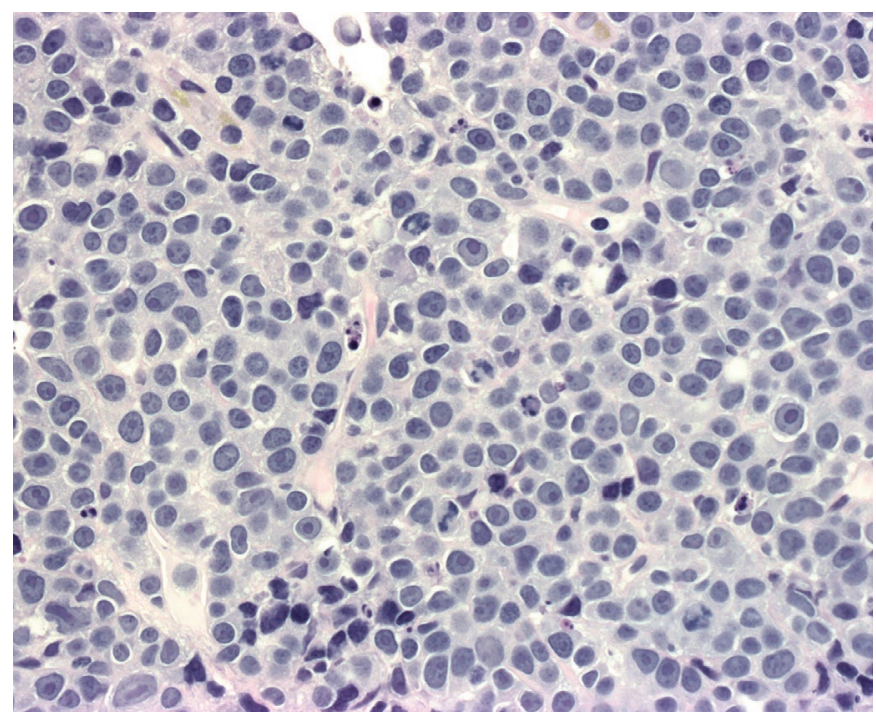

Figure 3. Hematoxylin \& Eosin stain of kidney tissue. Large discohesive cell population with malignant cytology. Note: Flow cytometric immunophenotyping studies performed on this biopsy specimen demonstrated clonal B-cell population, kappa light chain restricted, positive for CD19, CD10, CD20, CD38, and negative for CD5, CD23. 


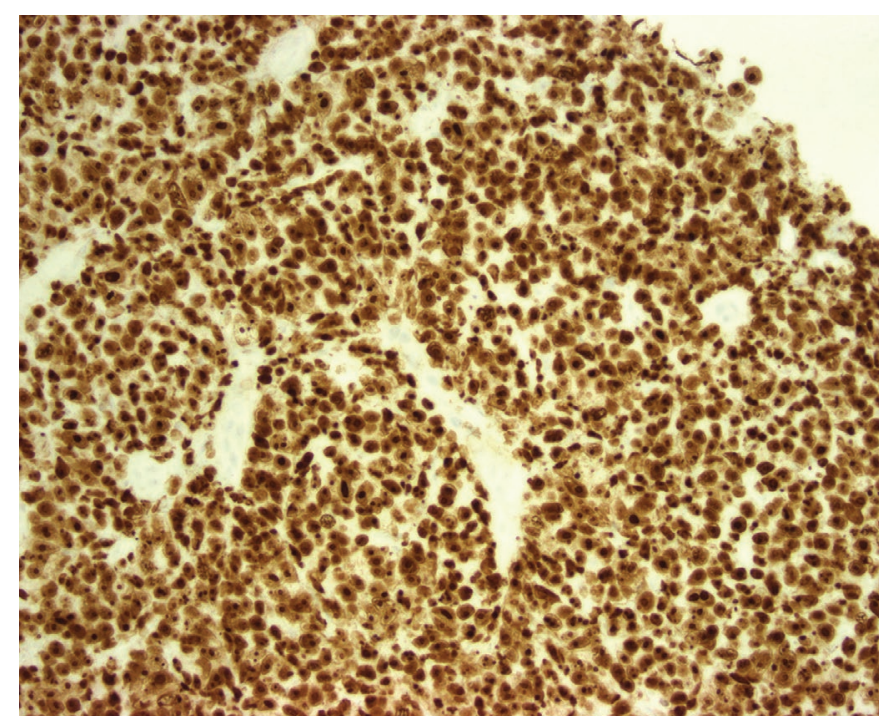

Figure 4. Immunohistochemical stain for MIB-1 (Ki-67) proliferation marker, showing positive immunoreactivity in virtually $100 \%$ of the malignant cells in the kidney biopsy specimen.

confirm the diagnosis. Nephrectomy can usually be avoided in patients thought to have lymphoma if diagnosis is made by biopsy when there are atypical features of renal cell carcinoma on imaging. The prognosis for primary renal lymphoma has been reported to be poor universally, ${ }^{15}$ as is also the case with secondary involvement of the kidneys by NHL. Survival has improved over the decades, which could be attributable to

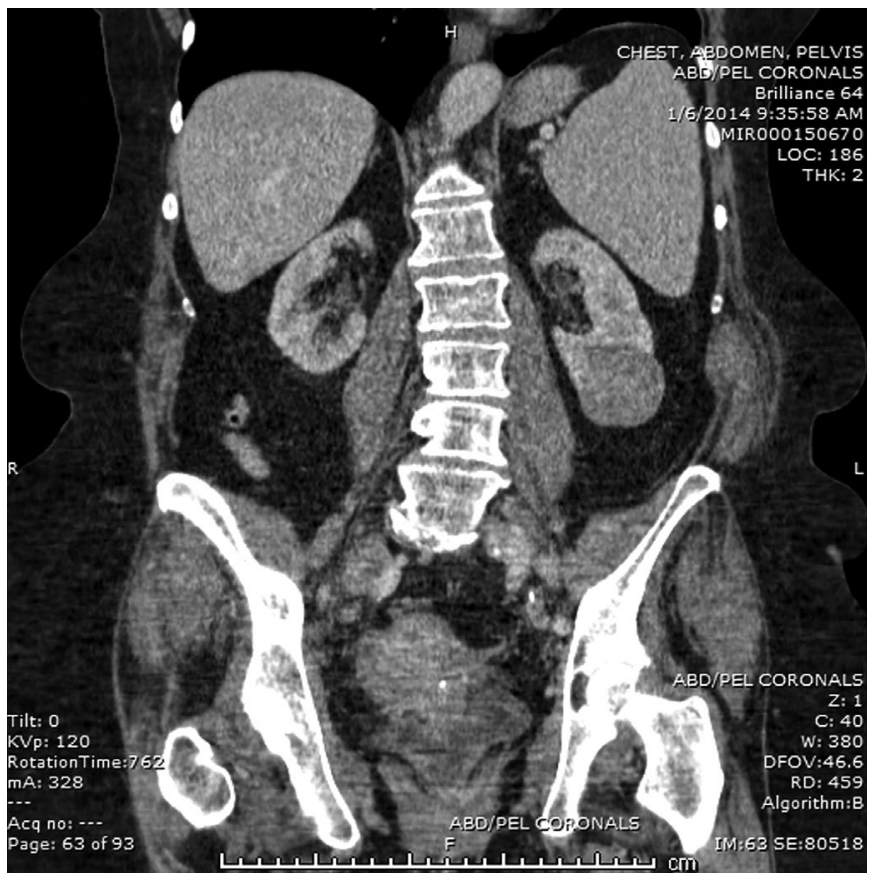

Figure 5. Abdominal computed tomogram demonstrating lymphoma in the left kidney.

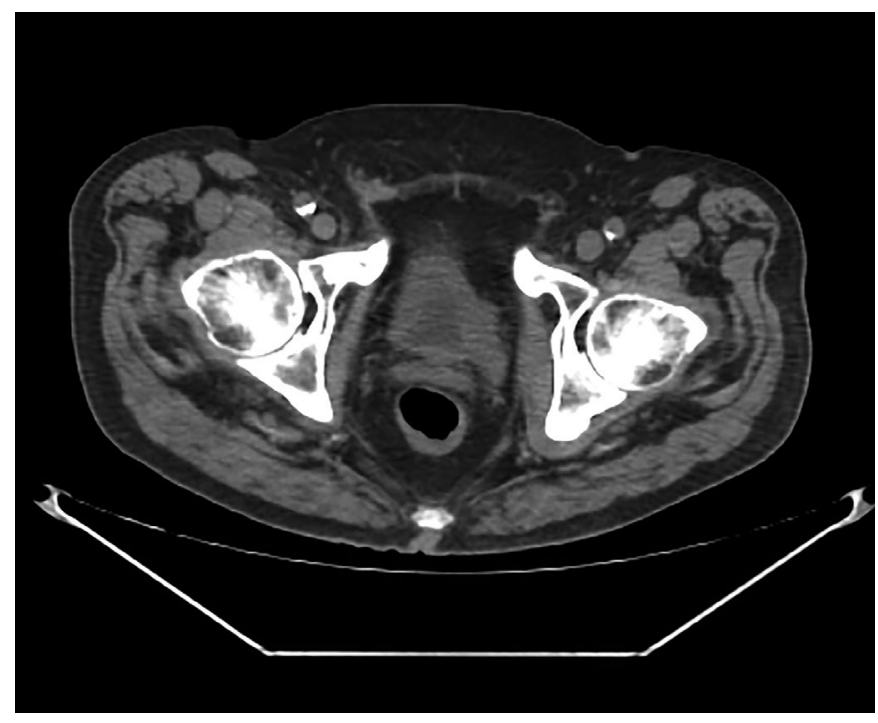

Figure 6. Abdominal computed tomogram demonstrating lymphoma in the left sidewall of the bladder.

improvement in supportive care and rituximab-based regimens. ${ }^{16,17}$ Patients in our case series had an average survival of 11 months. A fairly common urologic manifestation of lymphoma is ureteral obstruction due to retroperitoneal lymphadenopathy compressing the ureters. This may require placement of ureteral stents to improve renal function.

\section{Bladder}

According to findings from an autopsy series, the incidence of secondary involvement of the bladder in patients with lymphomas originating elsewhere was $13 \%{ }^{18}$ Like other primary GU lymphomas, however, primary bladder lymphoma is rare. Indeed, Kempton et al's ${ }^{19}$ retrospective review of the Mayo registry from 1940 to 1996 yielded only six cases. Pathophysiology of primary bladder lymphoma is unknown, because the bladder contains neither germinal follicles nor lymphoid tissue. Around $22 \%$ to $40 \%$ of reported cases were preceded by chronic cystitis, which suggests these lymphomas develop in the setting of chronic inflammation from cystitis. ${ }^{20}$ This would explain the higher incidence in women than in men. The most common presenting symptom is hematuria. Abdominal imaging may demonstrate a bladder mass (Figure 6). On cystoscopic examination, primary bladder lymphoma is usually seen as a solitary mass in the dome or the lateral wall of the bladder, rather than as diffuse lesions. In our case series, DLBCL and low-grade B-cell NHL were the most common histological subtypes, and there were two cases of Hodgkin lymphoma (Figures 7 \& 8).

Testis

Primary testicular lymphoma is a rare and aggressive form of extranodal lymphoma accounting for $<5 \%$ of testicular malignancies and $1 \%$ to $2 \%$ of NHL cases. ${ }^{21}$ It is usually diagnosed on physical examination when the patient presents 


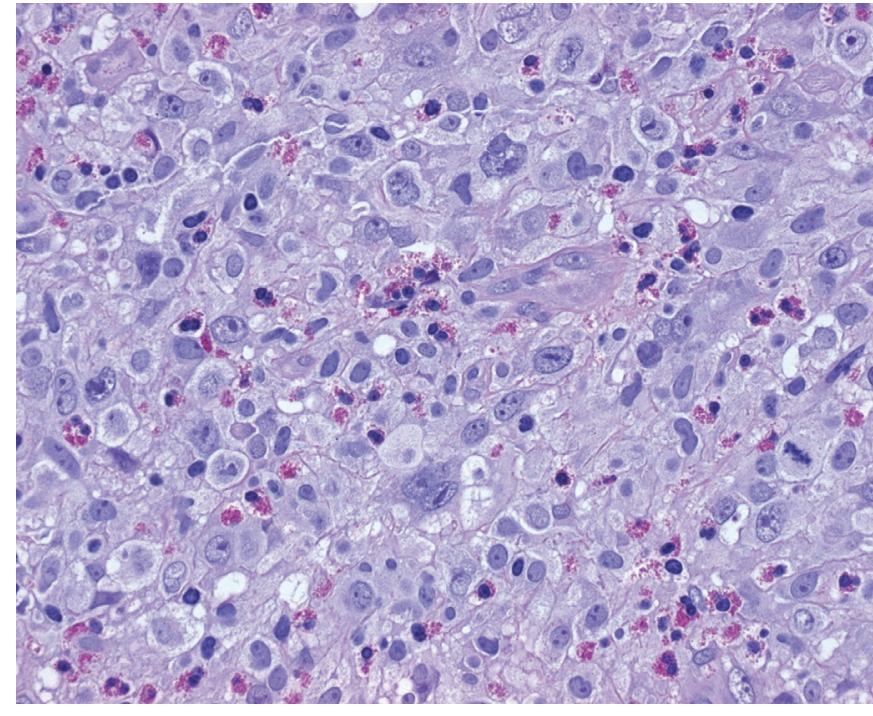

Figure 7. Hematoxylin \& Eosin stain of bladder tissue. Scattered large very atypical cells with binucleated and multinucleated forms (Reed-Sternberg cells) are present amidst an admixture of mixed inflammatory cells including many eosinophils, small lymphocytes and plasma cells.

with an enlarged, nonpainful testicle. Renal ultrasonography typically demonstrates diffuse enlargement of the affected testis (Figure 9). It is the most common testicular malignancy in men 60 years-of-age or older. ${ }^{22}$ A study by Ahmad et $\mathrm{al}^{23}$ found these patients presented as stage I or II disease at the time of diagnosis (60\% and $30 \%$, respectively), and around $35 \%$ had bilateral testicular involvement. The most common histological subtype is DLBCL, similar to our case series (Figures $10 \& 11$ ). Primary testicular lymphoma has a

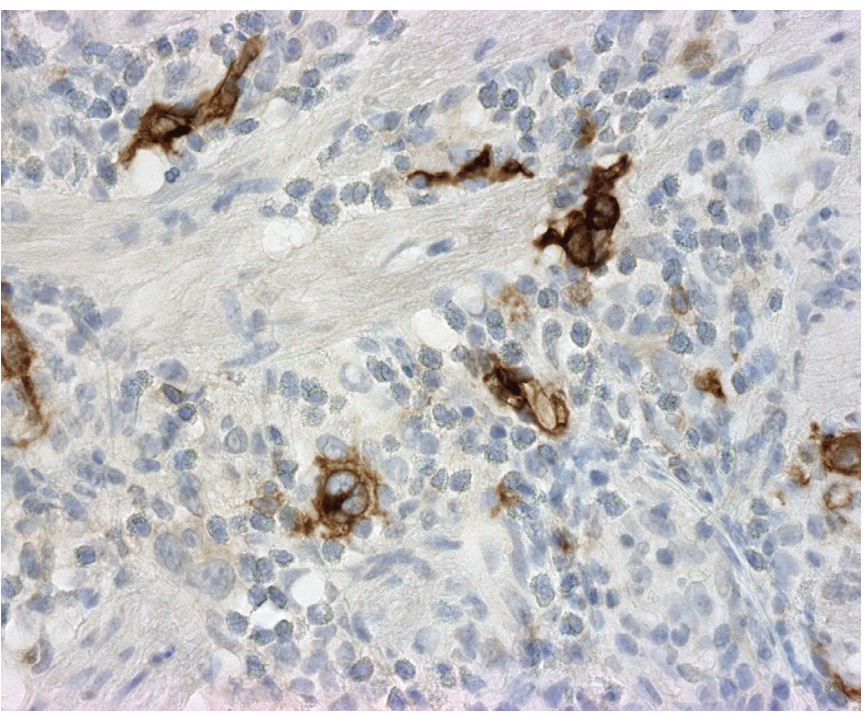

Figure 8. Immunohistochemical stain of bladder tissue which was positive immunostaining for CD30.

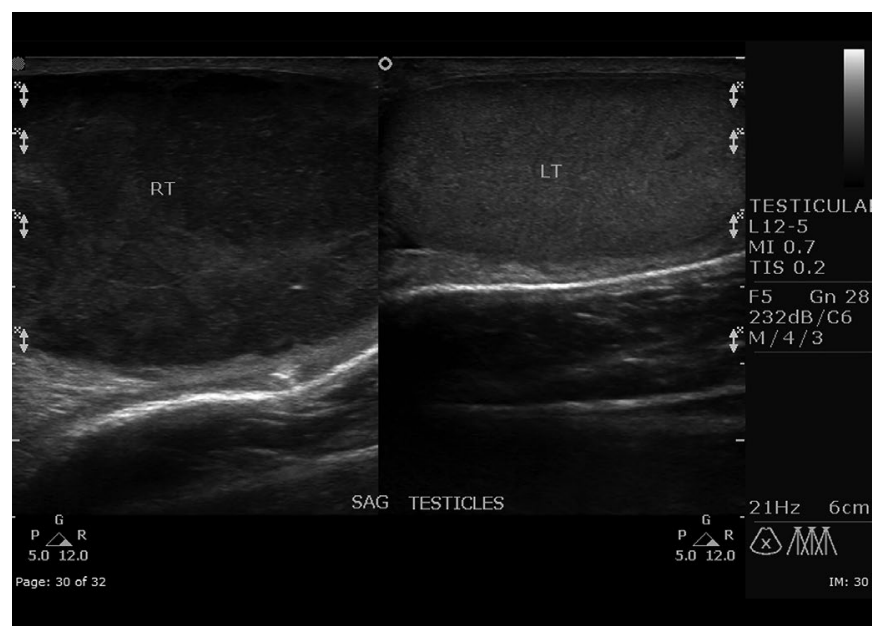

Figure 9. Testicular ultrasonogram demonstrating diffuse enlargement of the right testicle due to lymphoma.

remarkable extranodal tropism and relapses frequently in chemotherapy sanctuary sites such as CNS, contralateral testis, and also in pleura and skin. ${ }^{21}$

Patient age, B-symptoms, performance status, tumor larger than $9 \mathrm{~cm}$, spermatic cord involvement, elevated LDH concentration, histologic grade, vascular invasion, CNS involvement, Ann Arbor stage, and IPI score are known prognostic factors for primary testicular lymphoma. ${ }^{24}$ Outcomes have historically been poor. Studies have shown surgery as the sole treatment in patients with stage I disease to be insufficient, because most of these patients relapse within 2 years, ${ }^{22}$ with relapses occurring in the contralateral testis in around $5 \%$ to $35 \%$ of patients. ${ }^{25}$ This suggests these patients have widespread microscopic disease present at the time of

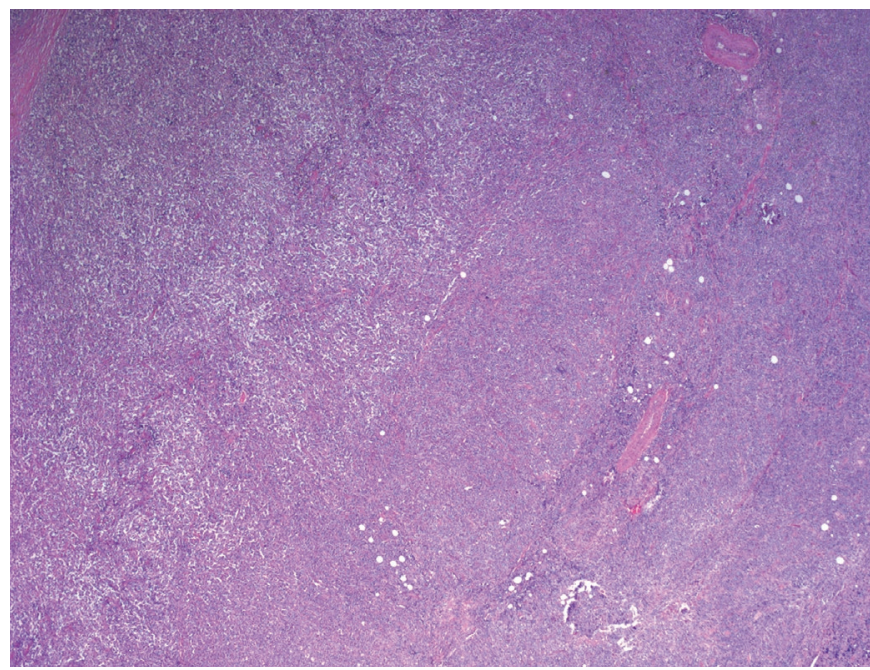

Figure 10. Hematoxylin \& Eosin stain. Low magnification showing diffuse sheet-like replacement of testicular parenchyma by large lymphoid cells. 


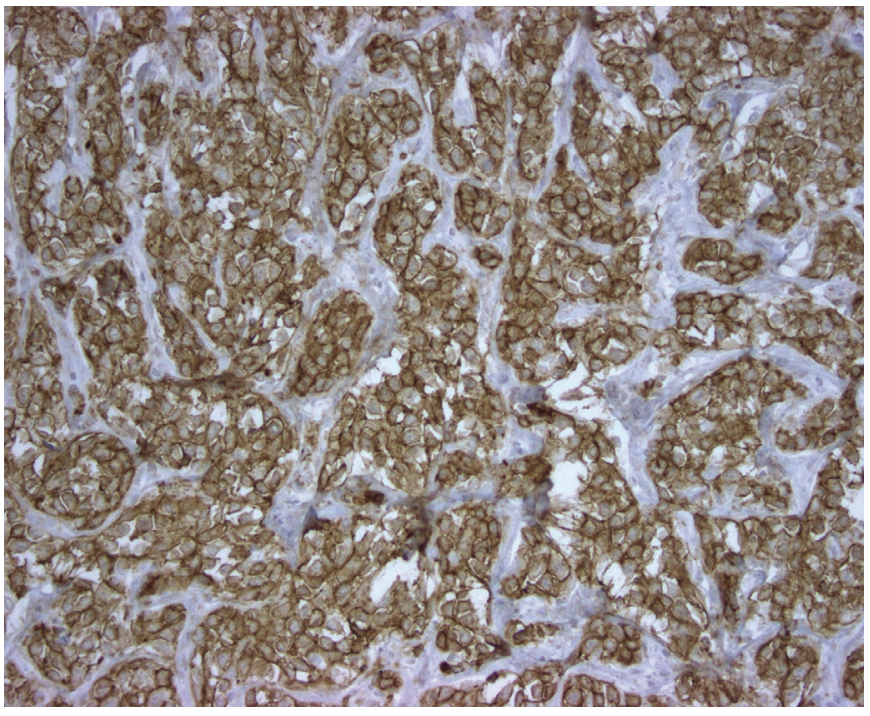

Figure 11. Testicular tissue demonstrating positive stain for the pan-B-cell marker CD20.

diagnosis. ${ }^{26}$ In our case series, the majority of patients had a longer survival of more than 10 years.

\section{Conclusion}

Although GU lymphomas are rare, our series confirms prior studies demonstrating their presentation in any urologic organ. They should be considered in the differential diagnosis in all patients, especially those with unusual findings on examination, cystoscopy, or CT scan. Although GU lymphoma is usually diagnosed by urologists, their ultimate care is provided by hematologists. This paper adds to our understanding of GU lymphoma's relative frequency and prognosis.

\section{Acknowledgment}

The authors thank Gundersen Health System pathologist Daniel F. Schraith, MD, for graciously providing the histological images and descriptions.

\section{References}

1. Cancer Stat Facts SEER. Non-Hodgkin Lymphoma. Bethesda, MD: National Cancer Institute. Bethesda, MD. Available at: https://seer.cancer.gov/statfacts/html/ nhl.html. Accessed August 8, 2019.

2. Schniederjan SD, Osunkoya AO. Lymphoid neoplasms of the urinary tract and male genital organs: a clinicopathological study of 40 cases. Mod Pathol. 2009;22(8):1057-1065.

3. Dawson IMP, Cornes JS, Morson BC. Primary malignant lymphoid tumours of the intestinal tract. Report of 37 cases with a study of factors influencing prognosis. Br J Surg. 1961;49(213):80-89.
4. d'Amore F, Christensen BE, Brincker H, et al; Danish LYFO Study Group. Clinicopathological features and prognostic factors in extranodal nonHodgkin lymphomas. Eur J Cancer Clin Oncol. 1991;27(10):1201-1208.

5. Vannata B, Zucca E. Primary extranodal B-cell lymphoma: current concepts and treatment strategies. Chin Clin Oncol. 2015;4(1):10.

6. Rao R, Bansal M, Raghuvanshi S, Ansari MS, Neyaz Z. Diffuse large B-cell non-Hodgkin lymphoma of the prostate presenting with urinary outlet obstruction: A case report. Urol Ann. 2015;7(1):100-103.

7. Fukase N. Hypoplasia of the rudimentary lymph nodes of the prostate. Surg Gynecol Obstet. 1922;35:131-136.

8. Humphrey PA, Vollmer RT. Extramedullary hematopoiesis in the prostate. Am J Surg Pathol. 1991;15(5):486-490.

9. Bostwick DG, Iczkowski KA, Amin MB, Discigil G, Osborne B. Malignant lymphoma involving the prostate: report of 62 cases. Cancer. 1998;83(4):732-738.

10. Terris MK, Freiha FS. Transrectal ultrasound appearance of hematolymphoid malignancies involving the prostate. Urology. 1998;51(2):339-341.

11. Okuno SH, Hoyer JD, Ristow K, Witzig TE. Primary renal non-Hodgkin's lymphoma. An unusual extranodal site. Cancer. 1995;75(9):2258-2261.

12. Omer HA, Hussein MR. Primary renal lymphoma. Nephrology (Carlton). 2007;12(3):314315.

13. Bora M, Das SB, Loitongbam R, Barthkur HS, Biswas T. An unusual case of primary bilateral renal lymphoma: a case report. Journal of Evolution of Medical and Dental Sciences. 2014;3(37):9679-9684.

14. Geetha N, Shahid A, Rajan V, Jacob PM. Primary renal lymphoma-a case report. Ecancermedicalscience. 2014;8:466.

15. Pervez H, Shaikh M, Potti A, Mehdi SA. Uncommon presentations of non-Hodgkin's lymphoma: case 3. Primary renal lymphoma. J Clin Oncol. 2003;21(3):567569.

16. Gundrum JD, Mathiason MA, Moore DB, Go RS. Primary testicular diffuse large B-cell lymphoma: a population-based study on the incidence, natural history, and survival comparison with primary nodal counterpart before and after the introduction of rituximab. J Clin Oncol. 2009;27(31):5227-5232.

17. Holdhoff M, Ambady P, Abdelaziz A, et al. Highdose methotrexate with or without rituximab in newly diagnosed primary CNS lymphoma. Neurology. 2014;83(3):235-239.

18. Sufrin G, Keogh B, Moore RH, Murphy GP. Secondary involvement of the bladder in malignant lymphoma. J Urol. 1977;118(2):251-253. 
19. Kempton CL, Kurtin PJ, Inwards DJ, Wollan P, Bostwick DG. Malignant lymphoma of the bladder: evidence from 36 cases that low-grade lymphoma of the MALT-type is the most common primary bladder lymphoma. Am J Surg Pathol. 1997;21(11):1324-1333.

20. Simpson WG, Lopez A, Babbar P, Payne L. Primary bladder lymphoma, diffuse large B-cell type: Case report and literature review of 26 cases. Urol Ann. 2015;7(2):268272.

21. Cheah CY, Wirth A, Seymour JF. Primary testicular lymphoma. Blood. 2014;123(4):486-493.

22. Vitolo U, Ferreri AJM, Zucca E. Primary testicular lymphoma. Crit Rev Oncol Hematol. 2008;65(2):183-189.

23. Ahmad SS, Idris SF, Follows GA, Williams MV. Primary testicular lymphoma. Clin Oncol. 2012;24(5):358-365.

24. Sathyanarayanan V, Suresh TM, Dasappa L, Kanakasetty GBK, Kuntegowdanahalli CL, Lokesh KN. Primary Diffuse large B-Cell lymphoma of testis: A single centre experience and review of literature. Urol Ann. 2014;6(3):231-234.

25. Koukourakis G, Kouloulias V. Lymphoma of the testis as primary location: tumour review. Clin Transl Oncol. 2010;12(5):321-325.

26. Ciatto S, Cionini L. Malignant lymphoma of the testis. Acta Radiol Oncol Radiat Phys Biol. 1979;18(6):572-576.

\section{Author Affiliations}

Yazhini Vallatharasu, $M D^{*}$; Adithya Chennamadhavuni, $M D^{*}$; and Marvin J. Van Every, $M D^{t}$

*Department of Medical Education, Gundersen Health System, La Crosse, Wisconsin, USA; Current Affiliation: Thedacare Regional Cancer Center, Appleton, Wisconsin, USA 'Department of Medical Education, Gundersen Health System, La Crosse, Wisconsin, USA; Current Affiliation: Hematology/ Oncology Fellow at University of Iowa Health Care, Iowa City, Iowa, USA

"Department of Urology, Gundersen Health System, La Crosse, Wisconsin, USA 